\title{
Editorial
}

\section{Making Space for Shakespeare in the Central European Imaginary}

Many people's engagement with Shakespeare happens in only two dimensions, when they read words on a page. This publication seeks to support a recent correction in academic theatre studies of this misperception of the artistic possibilities of Shakespeare by drawing attention to performance, and, in particular, to the three-dimensional, sculptural, tactile, multi-sensory and image-driven environments that so many scenic artists have created by for Shakespeare in the theatre.

Our special issue of Theatralia emerges from a larger research project involving partners in the Czech Republic, Slovakia, United Kingdom, and the United States of America. Specifically, Masaryk University, the University of Hull, and Ohio State University - each of which institutions hosted a conference on the theme of Czech and Slovak Scenography for Shakespeare during a three-year initiative: 2015 (Hull), 2016 (Masaryk) and 2017 (OSU). The second of these conferences, at Masaryk University, was sponsored by the Department of Theatre Studies and Theatralia and has led to this volume; the last, at OSU, was accompanied by a major international exhibition of Central European scenography: Shakespeare in Prague: Imagining the Bard in the Heart of Europe (a touring exhibit curated by Nannette Maciejunes, Joseph Brandesky, Vlasta Koubská and Barbora Příhodová; organised the Columbus Museum of Art; The Ohio State University's College of Arts and Sciences Arts Initiative; the Arts and Theatre Institute, Prague, and the National Museum, Prague).

Together, over the last few years, and international team of scholars has explored theoretical models for understanding the space, place and performance of Shakespeare. Approaches used have included phenomenology, Structuralist semiotics, sociological and historiographical analyses (including art-historical approaches) and scenographic theory. As a collective, we have analysed the work of the many Central European designers who have brought new visual insights to staging Shakespeare during the twentieth and early twenty-first centuries. Conference contributors have consistently been invited to consider the dramatic locations that are created in/through/by visual scenographic environments, as well as the theatrical sites or spaces in/on/at which such imagined 
locations are realised (i.e. the real historical theatres and cities). One central aim of all three conferences has therefore been to work towards theorised performative developments of the locus/platea (imagined location)/(real stage space) divide that was proposed in Shakespearean studies by the German scholar Robert Weimann in 2000. We have done this in order to develop more nuanced notions of the perceptual gestalt that occurs in watching any production of Shakespeare: those moments in which spectators simultaneously experience the play, its visually designed setting, and the cultural/ social/political site and space in which this specific performance unfolds. The methodological approach has been a significant step forwards for international Shakespeare performance criticism.

With regards to an understanding of the ways in which technology and aesthetics function in the creation of stage images, contributors in the project have also considered the work of practitioners for whom re-imagining the possibilities of Shakespeare has been linked to the development of new stage environments. In many of the papers written for the project, therefore, participating scholars have helped to re-define the spectrum of analytical practices that are currently used to understand the modelling of site, space, and performance in relation to Shakespeare. Repeatedly and insistently, contributors to the project have asked the following questions: What do scenographic environments bring to our understanding of Shakespeare? How do Shakespeare's texts offer extended possibilities for theatrical design and mise-en-scène? What does the cultural location of performance bring to the interpretation of text? How can visual and aural elements of scenography underscore/undercut actors' oral and physical deliveries of lines? How do particular trends in visual design (such as Nineteenth Century pictorialism, Cubist aesthetics, Surrealism and Poetism, Czech Action Scenography, site-specificity, or projection technologies) speak to contemporaneous critical trends in Shakespearean reception, both cultural and scholarly? What aspects of Shakespeare's dramaturgy have led to scenographic invention? and what can scenography tell us about the ways in which individual cultures, at precise moments of social history, are using Shakespeare to articulate notions of self, identity and nation?

Our project has thus set artistic interpretation alongside social, political, aesthetic, theatre historical and technological modes of analysis, in order to assess the significances of Czech and Slovak Shakespeare designs, with a particular emphasis on the social and cultural history of the Czech Republic, Slovakia and the former Czechoslovakia during the date range: ca. 1900 to 2015. 


\section{Why Shakespeare? Why Scenography? Why the Czech Republic and Slovakia?}

Czech and Slovak scenography is recognised world-wide as a first-class tradition of theatre culture. As such, our project's focus has been intended to have a normative influence on scenographic theory and theatre history across the world. Similarly, the focus on Shakespeare's works has played a key role, because this playwright in particular has been demonstrated in recent scholarship to be a transnational mediator with an equally normative global influence. In other words: just as Shakespeare has been used internationally since his own period as a writer whose philosophical messages speak to numerous issues of personal, cultural and political identity, so Czech [or/and] Slovak scenography has become the mediator of academic discourse relating to the theorisation of stage space. When translated and performed across the world, many nations and their peoples have found their voices through Shakespeare; but it is primarily through the theatrical staging of his plays in sculpted, kinetic, representational and/or abstract artistic environments that any culture begins to articulate locally specific, yet universally profound, insights into crucial aspects of the human condition. To date, very little academic research has been conducted into the relationships between the visual aesthetics of scenography and the cultural and political history of theatre. Our project intends to begin a move towards the rectification of this deficiency.

The Czech Republic and Slovakia are important candidates for such a study, too. Today's two independent nation states have not always been stable and defined territories. During the period considered in this volume (and by the wider research project), the modern Czech Republic and Slovakia have been variously incorporated into numerous disparate cultural and political figurations of nationhood. Culturally and linguistically Czech lands have been part of the multi-ethnic Central-European Habsburg monarchy, officially dominated by a German element; culturally and linguistically Slovak and Czech territories have been ruled as part of the Austrian or Austro-Hungarian empire; Czech and Slovak territories were brought together as one nation in the post-World War I project of a united Czechoslovakia. However, that new nation was all-too-quickly invaded by Nazi Germany (and notably the methods of Nazi control and domination were very different for the two regions). For most of the post-war period, Czechoslovakia was either occupied by Soviet forces, or was run as a satellite state of the former Eastern Bloc. More recently, but temporarily once again, Czechoslovakia achieved independence from communist control in 1989; before the constituent nations of the Czechoslovak amalgam separated in 1993 in order to form two new nations: the Czech Republic and Slovakia. Finally, of course, both countries joined an expanded European Union in 2004.

Such a turbulent cultural and political history can be used by scholars of art history, scenography and performance as an informative case-study of the ways in which threedimensional scenographic art, expressed through Shakespeare in particular, can be used as a vehicle for speaking to changing concepts of self, nation, and identity. The 
forms and shapes of Shakespearean scenography in Czech and Slovak lands over the last century or so can thus not only appeal to us from aesthetic, artistic and technical perspectives, but also from social and political ones.

\section{Who have we Studied?}

Scholars participating in the project have conducted academic analyses of some of the most significant artistic interpreters of Shakespeare ever to have lived: Martin Brezina; Peter Čanecký; Josef Čapek; Ján Hanák; Vlastislav Hofman; Ludovít Hradský; Alexandr Vladimír Hrska; Mikuláš Kravjanský; Ján Ladvenica; Jaroslav Malina; František Muzika; Oto Opršal; Ludmila Purkyňová; Otokar Schindler; Ján Sládek; Vladimír Suchánek; Josef Svoboda; František Tröster; Jan Vančura; Jozef Vecsei; Ladislav Vychodil; Josef Wenig; Karol Legenyi Zachar; František Zelenka and others . . .

In considering such a broad base of work, participants have analysed the unique contribution of Czech and Slovak designers to the production of visual art, taking Shakespeare as their touchstone. Some of the essays written for the global project appear in this volume, and further studies will be published subsequently.

\section{The Essays in this Volume}

Our collection for Theatralia begins with two essays about contemporary scenographic modelling. Cat Fergusson's piece 'Visualising Process: Hofman's 1926 Hamlet Reconstructive Practice' is a two-pronged account. It firstly deals with the ways in which modern computer modelling processes can shed light on the developing ideas through process of historical designers; secondly, it considers, through a detailed case study of Vlastislav Hofman's astounding Hamlet design (for the National Theatre in Prague) of 1926, the precise developments of one particular design and the attempts of the artist creating it to synthesise several dominant but competing trends in European art (Czech Cubism, Russian Constructivism and German Expressionism) into a workable series of stage structures. Dan Matthews' 'A Technical and Contextual Analysis of Scenography Through Sculptural Reproduction: Hofman and Tröster's Hamlets' takes this same topic, but focuses on outlining the responsive processes of maquette making undertaken by Matthews in his preparation of an accurate scale model box for public scrutiny during the Columbus Museum of Art Shakespeare in Prague exhibit.

Vlasta Koubská's essay takes our volume on another historical turn, this time combining an account of her discovery at Ohio State University of a photograph of Antonín Heythum with an artist's biography, 'The Scenographer Antonín Heythum and His Work in the US: The Case of King Lear' considers not only one designer's Avant Garde staging for a production of Lear in New York; it also outlines the influential situation of politically-motivated émigré artists working at The New School and elsewhere, bringing the invigorating artistic practices of Central Europe to the United States in 
the mid twentieth century. In 'From Creating Spaces to Evoking Images. $4+1$ Hamlets in Slovak Theatre' Jana Wild continues the volume's socio-political analysis with a consideration of the various ways that this one play (so central to the cultural identity of many Slavic peoples) has been used as a mirror not to nature, but to the constrained and manufactured political times of Slovakia from the period of high-Stalinism to the neoliberal sleepwalking of 2004.

Taking one particular Slovak designer, Zuzana Koblišková considers 'Ladislav Vychodil's Approach to Designing Stages for Shakespeare at Home and Abroad'. Koblišková's single-designer analysis considers the emerging trends and practices of Vychodil; and also the ways in which cultural location (in either communist Czechoslovakia or in the West) also had a significant influence on the design strategies employed. Ewa Tomaszewska's 'A Midsummer Night's Dream in Polish Puppet Theatres in Silesia - Mise-en-Scène by Jan Dorman, Josef Krofta and Marián Pecko' looks at a particularly strong set of international collaborations by Jan Dorman with Czech and Slovak designers for three performances of one central Shakespeare comedy at the Teatr Dzieci Zagłębia (The Zaglebie Children's Theatre) in Będzin (1965), the Wrocław Puppet Theatre (2003) and in the Puppet Theatre 'Banialuka' in Bielsko-Biała (2013). Tomaszewska's article draws out the symbiotic relationships between the intellectually open and Avant-Garde Polish theatre tradition and the strong trends of scenographic and puppet training available in the Czech Republic and Slovakia's training academies.

Moving us back to Moravia, Dagmar Inštitorisová's piece, 'The Scenography of Shakespearománie I.-III. [The Shakespearomania Trilogy] directed by Peter Scherhaufer at the Goose on a String Theatre in Brno' outlines the ways in which this 1988-1993 trilogy of performances used experimental dramaturgy and radical staging aesthetics to render both current and vibrant the key political and thematic issues present in a variety of well-known Shakespeare texts. During the period in question, there was a somewhat condescending saying in Prague: 'There are three types of theatre: good theatre, bad theatre . . . and theatre from Brno.' The joke (that what passes for theatre in Brno is actually something quite else), although intended as a slight towards the Moravian metropolis' theatre culture, was actually a strong compliment - because the company that is the focus of Inštitorisová's piece, Divadlo Husa na provázku (Goose on a String Theatre), and others of its ilk at that time intentionally sought to push the boundaries of what was possible in theatrical performance. Something perhaps not possible in selfassured Prague.

Looking at 'Othello and the Perception of Race within the Cultural Context of Czech and Slovak Theatres', Zuzana Koblišková's second essay in this volume provides the first outline study of the ways in which Shakespeare's difficult play about racial hatred and jealousy has failed, until very recently, adequately to address the thorny issue of racial identity in Slovakia, most probably because of the innate and often-unseen racial prejudice of her country of birth. Prompted by a keynote lecture by Christian Billing at the Brno Theatralia conference of 2016 (analysing 'Race as Scenography in Jozef Ciller's Set Design and Katarína Holková's Costumes for Rastislav Ballek's Production of Othello at 
the Národní Divadlo, Brno (2014)'), Koblišková's brave response is an honest appraisal of a problem in both Slovak theatre and culture.

Albena Tagareva's essay focuses on the scenography in the style of Socialist Realism in the National Theatre in Bulgaria. The author deals with the question of how the standards of Socialist Realism transformed stage design in Bulgaria after the coup of 1944. She examines the processes, influences and concepts connected with the work of stage designers working for the National Theatre during the totalitarian Communist regime. Tagareva's article presents the outcomes of a broader research project focused on clarifying the development of Bulgarian scenography as well as the personal art style of selected generations of set designers from the point of view of today's stage design research. In her essay she examines the desperate situation in which the stage designers worked and their struggles with the Communist regime and the normative aesthetics of Socialist Realism.

Helena Spurná's article 'The Political Dimension of the Performance Jeanne d'Arc au bûcher [Joan of Arc at the Stake]' focuses on a particular production of Arthur Honegger's oratorio in the Janáček Theatre in Brno. The production of Honneger's Oratorio in 1969, until today considered a remarkable dramaturgical contribution, was directed by Miloš Wasserbauer, an outstanding opera director of the period. The opening of the production took place just a few months after the self-immolation of Jan Palach, a young student who burned himself to death as a protest against the 1968 invasion of Czechoslovakia by the Warsaw Pact armies. For this reason, the production raises the question as to whether it can be interpreted as a political act. Spurná discusses the context of the Jeanne d'Arc au bûcher in the repertoire in the time of tumultuous political changes in Czechoslovakia.

The special issue concludes with two important interviews: Vlasta Koubská's 'Interview with Jan Dušek' takes the man who is the head of the Department of Stage Design in the Theatre Faculty of the Academy of Performing Arts in Prague (DAMU) through a structured recollection of the circumstances and guiding principles of his many designs for Shakespeare. Koubská's interview is excellent at drawing from Dušek many of the details relating to the social and political circumstances of his work, as well as the ways in which his active and open collaboration with actors, directors and technicians has led to some of the most striking (and chilling) of recent performances of Shakespeare's greatest plays.

Radka Kunderová's interview with Matthias Warstat, Professor at the Institut für Theaterwissenschaft at the Freie Universität Berlin, and co-director of the Research Centre Interweaving Performance Cultures in Berlin, who in his research focuses on theatre and society, the theatricality of politics, performance and rituality, and theories of aesthetics. The interview entitled 'We Must Take these Risks' outlines some of the key challenges facing academic theatre studies in Europe; before lastly Warstat's own contribution: 'Obamovo tělo. Performativní aspekty politické rétoriky'. In this issue, we bring the ground-breaking study by $\mathrm{M}$. Warstat in a brand new Czech translation by Marie Kunderová and Radka Kunderová. On the example of Barack Obama, Matthias Warstat analyses the role of the body in political performances. 
The section 'Reviews' includes a remarkable variety of topics. It includes two books on Shakespeare and a review of a recent publication on British musical. One of the reviews provides a detailed comment on the Theoretical Issue of Anglia Journal and on a Follow-up Symposium. The Concluding review of this section comments on a television documentary focused on Ancient theatre.

Three reports in the section 'Events' focus on up-to-date developments in theatre and theatre studies. In this issue we include two reports from recent conferences and an enquiry including commentaries on the special concert performance of extracts from the opera Guilt by Otakar Zich.

In the 'Appendix' to the volume we present the very first translation from Latin to Czech of Curculio (Darmojed). This ancient Roman comedy, more than two thousand years old, authored by Titus Maccius Plautus, is translated into Czech by the interdiscilinary team of translators: Tomáš Weissar, Eliška Poláčková, Daniela Urbanová and Radek Černoch. The team based their work on an in-depth dramaturgical analysis of the ancient play and this analytical approach makes it accessible to Czech readers and audiences of today.

We would like to thank to the team of the Department of Theatre Studies and the Dean's Office of the Faculty of Arts of Masaryk University who supported our efforts in editing this volume, to the authors who contributed to the volume, to the peer-reviewers of the essays, and last but not least to the scholars and friends who participated in or supported the project 'Czech and Slovak Scenography for Shakespeare'.

Christian M. Billing (University of Hull) Šárka Havlićková Kysová (Masaryk University) 
